\title{
4
}

\section{Confucianism and the conception of the law in Vietnam}

\author{
Pham Duy Nghia
}

Confucianism in Vietnam originated from the Vietnamese people's agricultural lifestyle and continues to influence society today. As a set of social norms, Confucianism not only substitutes for the law in many aspects of life, but also contributes heavily to the conception of the law in Vietnam. Analysing Confucianism's impact will help us to understand better the role and limitations of the Vietnamese legal system today.

With the growth of the market-oriented economy, legal reform in Vietnam has entered a new stage where emerging paradigms are challenging the outdated doctrine of 'socialist legality'. Western legal models are increasingly providing the basic framework for new legislation, as can be seen in recently enacted legislation on business organisations (The Law on Enterprises 1999), contracts (The Commercial Law 1997, Civil Code 1995), dispute resolution, and bankruptcy (Ordinance on Commercial Arbitration 2003, Bankruptcy Law 1993). The increased levels of discussion on the Constitution, the protection of individual rights, and the need for a 'socialist state ruled by law has been coupled with increasing levels of awareness amongst civil society' (Amendment of the Constitution in 2001). As citizens become increasingly wealthy, however, they tend to become increasingly reflective of their historic and cultural roots. As a consequence, Confucian classic literature is enjoying a period of revival in Vietnam.

Following a long period of isolation, food shortages and emigration, Vietnamese society is undergoing rapid change, a crucial element of which is evolution of the law. In this transitional stage, enforcement of the law is imperative. Legal ideas adopted from the West face difficulties when implemented into a society where traditional forces resist change. In economic, political and cultural fields, the divergence between the written law and its application is widely evident. While the Constitution protects citizens' rights, the authorities' wide scope for misinterpretation is not effectively constrained by public claims and denunciation 
alone. For instance, the freedom of citizens to conduct business and compete fairly in the market faces ostensible restrictions imposed by the administrative authorities. Public faith in the judicial system is still limited, and the number of cases being heard before Vietnam's economic courts is, in fact, decreasing every year, despite the steady economic growth. ${ }^{1}$

To appreciate the current situation in Vietnam, one needs to look back to the past to understand the way in which the Vietnamese govern their society based on their beliefs and culture. Although laws to facilitate business activities are badly needed, they cannot substitute for the social norms that have dominated the Vietnamese agricultural society for centuries. Thus, when concepts such as limited liability in corporate law, for example, are introduced into the Vietnamese legal system, their application will take different forms from that in Germany or the United States. Thus, despite the various ways of harmonising the law and legal practice in the age of globalisation, one cannot ignore the impacts of tradition and cultures in forming the conception of the law in a given society (Örücü 1999).

The process of legal harmonisation in Vietnam has not been smooth. One contributing factor is that Vietnamese legal scholars, trained in former Soviet Union and East Germany, are surprisingly unfamiliar with their own legal traditions. Textbooks used in courses at major law schools, such as General Theory on State and Law, define the law according to Klassenkampf-the law is considered substantially as a tool used by the ruling class to exploit the working class. In legal history courses, legal development is described to fit the Marxist vision of a society progressing from slavery to feudalism, capitalism and finally towards a socialist communist state. Students learn by rote the five different types of state and laws, and try to place all statutes and laws within this prescribed format. Although courses in the 'History of Political Doctrines' are taught, their aim is to introduce the evolution of political philosophy according to the Marxist view.

The role of traditional law and its interaction with ethics and other social norms is not well researched within Vietnam. The discrepancy between the recent development in Vietnam and the backward style of research and teaching is a negative reflection, not only of the development of legal jurisprudence, but also most other social sciences in Vietnam (Phan Dien 2003).

In other countries, such as Japan, Korea, Taiwan, Singapore, and more recently China, ideas such as 'Asian values' and 'Confucian society' indicate the impact of traditional culture on contemporary legal and economic development. What lessons, if any, can Vietnam learn from the experiences of these countries? How can the traditional conception of the law continue to be protected and promoted as Vietnam moves to adopt laws based on Western models?

This chapter seeks to discuss the role of social norms in Vietnamese society, and in particular the contribution of agricultural social norms to the formation of Confucianism. It also uses the concept of 'Vietnam's Confucianism', initially presented by the scholar Kim Dinh $(1969,1970)$ to evaluate the past and present role 
of the law and its limitations in Vietnamese society. To this end, I will try to indicate the extent to which traditional agricultural social norms have influenced legal practice in Vietnam today.

\section{ORIGIN AND MAIN FEATURES OF VIETNAMESE CONFUCIANISM}

Vietnam was, and still is, a country that depends on its agricultural industry, with approximately 80 per cent of the workforce employed in that sector. At the same time, most of the urban population still lives in, or feels a connection to, the village of their ancestors. ${ }^{2}$ The success and failure of any contemporary reform in Vietnam cannot be explained without taking into account the problems facing Vietnamese farmers.

As a set of enforceable rules imposed or recognised by the state power, the law has never had supremacy in Vietnamese society. The social norms that govern Vietnamese society have been drawn largely from Vietnamese agricultural life, and continue to live in the beliefs of the people. The way people think influences the way they act; learning from their beliefs helps to explain their actual behaviour. It is therefore appropriate to search for the sources of Vietnamese indigenous norms in order to understand the present legal practice.

From a Western perspective, with the exception of the penal rules in the traditional codes (Le Code 1460 and Nguyen Code 1813), the indigenous norms in Vietnam remain somewhat unclear, originating as they did from the interchange between three leading religions in East Asia-Daoism, Buddhism and Confucianism. Historians often view Vietnam's culture as a mixture incorporating Chinese and Indian influences into the indigenous culture. Marxist materialists have little interest in researching and promoting such religious thinking. It is well known that Marx saw religion as the 'opium of the people' and an expression of the hope of the suppressed mass for a brighter future. Given that generations of Vietnamese, including the Communists and their followers, continue to maintain the cult for their ancestors, and given the increasing public interest in Daoism, Buddhism and other natural beliefs, it is surprising that Vietnamese religious thinking is rarely researched in contemporary Vietnamese Marxist literature.

It is thus an appropriate time to rediscover the role of Confucianism in contemporary Vietnamese society. Following discussion about Nguyen Truong To's work in the second half of the nineteenth century and the reprint of Tran Trong Kim's standard work on Confucianism, a number of scholars have raised questions relating to the role of Confucianism in contemporary society (Tran Van Giau 1988). The work of Vu Khieu (1997) and Phan Dai Doan (1998) reverberated in academic circles as a signal for a possible change in public opinion towards the once-leading ideology of Vietnam: Vietnamese Confucianism.

Confucianism is the only term known in the West for 'Nho giao'. During the chaotic Spring-Autumn and Warring States period, Confucianism emerged as one 
of many schools of thought that sought to provide order to society. Although Confucius was its the most famous teacher, he was not the creator of a new religion; the five classical works incorporated the wisdom of many generations (Tran Trong Kim 1971; Nguyen Hien Le 1958; Tran Le Sang 2002). During the ten centuries of Chinese domination in Vietnam, Confucianism was introduced into the modernday areas of North and Middle Vietnam (Nguyen Dang Thuc 1967), and continued to exist in harmony with other religions, such as Dinh, Ly and Tran, under Vietnam's first independent dynasties. During this time, the three religions used different 'ways' to reach the same goals (tam giao dong nguyen). In the transition from the Tran to the Ho dynasty, the influence of Confucianism intensified and extended from the capital down to the district levels. Confucianism became the leading ideology of the Vietnamese monarchy from the Le dynasty, particularly under the reign of Le Thanh Ton (1460-97). From that time until the early twentieth century, the traditional state of Vietnam, the recruitment of mandarins, and the organisation of society as a whole, were based on Confucian values and examinations (Phan Dai Doan 1998, Nguyen Dang Thuc 1967). The last Confucian examinations were conducted between 191518 in Northern and Middle Vietnam respectively (Tran Truong Kim 1971).

It is noteworthy that, as a system of rules governing people's behaviour, the face of Confucianism was dynamic and constantly changing, and incorporated both indigenous beliefs and norms. As a result, Confucianism took different forms in China, Japan, Korea and Vietnam. For example, loyalty in Japan was interpreted to mean loyalty to only one imperial family; loyalty in Vietnam, by contrast, focused on loyalty to the country as a whole and on defence of the nation. ${ }^{3}$

Vietnam's Confucianism cannot be viewed simply as being the ideology of the Chinese occupiers. Long after the occupiers had gone, the ideology remained and expanded to generate the standard norms that would govern the society for centuries. In this regard, the following explanations appear most plausible

- convergence between Vietnamese indigenous agricultural norms and Confucian values may have enhanced the broadening of Confucian values in Vietnam centuries after independence from China in 939AD

- in comparison to Buddhism and Daoism, Confucianism offered a doctrine more appropriate for the ruler's class to govern Vietnamese society

- based on archaeological, historical and anthropological evidence, relevant sources indicate that the ancestors of the Vietnamese people must have occupied the areas south of the Yangtze River in China. Under pressure from the Hoa people, they moved southwards, and the resulting meeting and mutual integration of Vietnamese agriculture and the nomadic Hoa culture possibly formed the wisdom that Confucius referred to as the wisdom of ancestors (Dao Duy Anh 1937, 1950; Nguyen Dang Thuc 1967; Kim Dinh 1970).

The scholarly works of Kim Dinh sought to trace the contribution of the Vietnamese people in establishing Confucian values, but what are the specific characteristics of Vietnamese agricultural life that contributed to this? Which features 
dominant in Vietnamese culture helped promote the convergence of Confucianism with the indigenous beliefs and traditions? A number of features of agricultural life appear relevant

- Collectivism. Vietnamese collectivism is distinct from communitarian attitudes in the West. A human being is born to be a member not only of a family, but a village and, in a broader sense, a member of a country. He or she lives in natural connection with other members of the society, as an integrated part of one organic body.Under such a system, the collective interest of society is supreme over individual interests; people who fight for their own interests are often viewed as selfish and egotistical (Marr 2000). This natural mindset of collectivism is born from the common efforts to cultivate crops. It is a major characteristic of the Vietnamese mentality and, at the same time, an essential factor hindering the emergence of individualism in Vietnam.

- Rule of causality. As a nation of farmers, the Vietnamese learnt the rule of causality (nhan-qua) very early. This rule suggests that whatever happens today has been caused by past events. In the views of the people, justice practised by the heavens is absolute and the actions of parents affect the destiny of their children. Accordingly, success or failure, wealth or poverty, peace or war are not random events; their reasons lie deep in human behaviour (Nguyen Tai Thu 1993).

- Life is to endure. Living in the highly populated river deltas, struggling to survive under the steady pressure of the dominant neighbours in the North and coping with endless obstacles, the Vietnamese have learnt to endure life. As a result, the Vietnamese life motto is to endure all challenges. As the Vietnamese say, 'if you are too clever, you will perish; if you are too stupid, you will also perish; but if you know how to live, you will survive [Khon chet, dai chet, biet thi song]'. This mentality may explain the elasticity and flexibility of Vietnamese people's behaviour.

- Harmony and consensus, not conflict. The need to maintain balance and harmony is stressed in all aspects of life, from family, to lineage, to village and state issues, and acknowledged by most Vietnamese. Although the man is traditionally considered head of the family, Vietnamese women have also enjoyed considerable equality and rights. In issues relating to the lineage of people with the same ancestors, decisions were usually made by consensus. The same principle may be seen in the structure of the villages, where consensus building is the major force keeping the village in order. Even though there were some indications of power struggles, instances of personal politics or cult-infused leadership were quite mild in communist Vietnam compared to China or North Korea.

- Face saving and relationship keeping. As a consequence of collectivism, the respect and opinion of the community is crucial to the life of each individual in Vietnam. The success of a person is dependent their 
trustworthiness and their ability to build and maintain relationships with other people. Fear of bad public opinion still motivates the Vietnamese.

- Respect for elders. Cultures based on agriculture have great respect for the elderly. This respect is reflected in decision-making in the villages, and frequently also in traditional law. As the demographic structure and socioeconomic conditions in Vietnam change, the traditional respect accorded to the elderly may face serious challenges.

- Nhan-Nghia. The Vietnamese term nhan corresponds to the Chinese counterpart ren, and remains one of the most difficult concepts of Confucianism. This term can only roughly be translated into the English 'benevolence'. According to Tran Trong Kim (1971), the purpose of lifelong self-cultivation is to learn benevolence, mercy, charity and humanity. As a result of this lifelong learning a man will receive the ability to love and hate, virtues that form the kernel of his behaviour. The extent of knowledge of the nhan will essentially distinguish the gentleman from the uneducated. The Vietnamese nghia corresponds to a notion of 'righteousness' and noble obligation towards family and the community. If nhan refers to a man's virtues, nghia refers to his responsibility towards other people and the society where he lives. This unwritten, undefined ethical rule creates the framework and boundaries to distinguish the Confucian gentleman (quan$t u$ ) from the uneducated (tieu-nhan). Naturally, the particular ethical values of this rule governing human beings may change occasionally, but over time this rule encourages people to behave well towards others and society generally.

When one considers the social norms governing the agricultural life of the Vietnamese people, similarities with Confucian values become apparent. Historians often discuss the question, first presented by Kim Dinh $(1969,1970)$, whether the Vietnamese culture contributed to Confucian values, or whether Confucianism, once introduced, became deeply rooted in, and a guide to, the behaviour of the Vietnamese. Regardless, social norms continue to govern Vietnamese society from one generation to another, alongside the written law.

\section{THE DECLINE OF CONFUCIANISM IN VIETNAM AND THE EMERGENCE OF SOCIALIST LEGALITY}

A class of Vietnamese Confucian scholars emerged during the first Chinese domination from $111 \mathrm{BC}$ to 937AD, but their presence went unnoted in historical reports. Their role in the first independent dynasties did not seem significant, since the sword had more power than philosophy. The most literally educated élite class in Vietnam at that time was the Buddhist monks, who served as advisers to the courts, helped receive Chinese ambassadors, and whose temples served as educational centres (Nguyen Dang Thuc 1967). As the influence of Confucianism grew in the thirteenth century, however, the monks' role in politics decreased. 
Vietnamese scholars used Confucianism to fight against the Chinese occupiers during the wars against the Chinese Minh dynasty. Thereafter, the social prestige of Confucian scholars improved-mandarins were recruited based on Confucian examinations, and a state bureaucracy began to form based on Confucianism (Phan Dai Doan 1998).

Confucianism became a political doctrine in the hands of the ruling class. Le Thanh Ton codified the Confucian values in books that were widely distributed to the villages, and private Confucian schools helped to broaden the Confucian values from the élite class down to all levels of the population. In addition, during its expansion, Confucianism also incorporated the values of other religions, such as Buddhism, Daoism and other natural beliefs. For this reason, even though it was not created as a religion, the population had already been practising Confucianism, albeit in an indirect manner.

As Confucianism is a political doctrine, the following features may help to understand the role of the law in Confucian society.

- Confucianism recognises the divisions within society between different classes - each man shall learn to act appropriately for his status in society. Gentlemen shall know the way to live, shall know the ' $i$ ' as rituals and rules governing relationships among people. By doing so, the man educates himself to become a gentleman, thus keeping his family, country and the state in order. The law seeks to enforce good behaviour amongst individuals by punishing those people who don't know the ' $l i$ '. Individuals therefore have an incentive to learn and practise the ' $l i$ ' in a way that enhances social order, and the law is consequently subordinated under the moral rules of ' $l i$ '. Despite some provisions in regard to property and contracts in the traditional codes, one can assume that the private law tradition in Vietnam is rather weak, suggesting that there was no need for such a set of legal regulations.

- The hostility inherent in legalism was criticised as being contrary to Confucian principles. Confucian values, however, may be interpreted as arbitrary because of the lack of clear, systematic and transparent rules. The people were once considered to be the roots of the country and the ruler's mission was to serve the people. Later, the feudal mandarins shifted this to focus more on the obedience of the subjects to the rulers, thus making the ruler like a god-the son of heaven. Moral values have their limitations, especially in times of economic strain. The backward-thinking style of Confucianism sometimes produced reactionary forces that opposed reform. In Vietnam, for example, reformers like Ho Quy Ly, Nguyen Hue and later, Nguyen Truong To, faced resistance, particularly from Confucian scholars and mandarins.

- The question is not to make a choice between legalism and Confucianism, but rather to 'Confucianise' the law, as was done during the Chinese Han dynasty. Law reform was enhanced under the Le and Nguyen dynasties, 
and particularly under Minh Mang. Legislation, including the formal requirements for lawmaking and the scope of regulation, was codified and standardised. Confucian values were newly underpinned by penal sanctions-thus Confucian values were transformed into enforceable norms.

Numerous peasant uprisings at the end of the seventeenth century signalled a reaction to the backward thinking of Confucianism and its weaknesses in managing the country.

1 The intellectual class had confined itself to the classics of Confucius and Mencius. The social and natural sciences were not taught. The teaching style, moreover, focused on rote learning, thus blocking new ideas and learning from Western civilisations.

2 The ruling class-from the king to the mandarins-relied on the bureaucratic style of government and required absolute obedience from the subjects.

3 The peasants were mentally and physically closed from the world behind village walls. Vietnamese society, from its rulers to the peasants, remained a relatively closed society until the late eighteenth and early nineteenth centuries. Foreign merchants settled in Pho Hien (North Vietnam) and Hoi An (South Vietnam) but left the country (partly because of the hostile policies of the Trinh and Nguyen lords toward Christianity) without being able to make any notable changes to the Vietnamese attitude towards the outside world.

The enemy keeping Vietnam impoverished lies deep in the Vietnamese soul. Reformers in the nineteenth century attempted to redefine traditional values in order to open up the country by promoting trade, consumption and by enabling foreigners to invest and conduct business within the country. These benefits were lost, however, in the silence of the closed and traditional society. Confucianism heavily exploited the popular belief in the necessity of obedience to the rulers, even in the face of their backward thinking. Not surprisingly, when faced by Western civilisations, this did not succeed.

Vietnamese intellectuals looked to foreign ideas for ways to rescue the independence of their country. This had already failed under French domination, when Vietnam was heavily exploited and suppressed by the colonialists. Having no chance to explore liberalism, the Vietnamese people bitterly learned of the dark side of capitalism. They therefore began to embrace socialism and socialist ideals under the influence of French colonialists. Nationalism, combined with Communism's general principle of equality, essentially helped the Communists to succeed. Confucian values and ethical standards were frequently borrowed in the effort to mobilise the masses, and new interpretations were made to fit the needs of long-lasting liberation and a war against the foreign occupiers.

Once in power, the Vietnamese Communists did not fight Confucianism as bitterly as did their Chinese counterparts, but the social prestige of Confucianism was 
essentially destroyed. In the political sphere, Marxism-Leninism replaced the Confucian worldview - the puppet son of heaven abdicated its power and was replaced by the people's republic, which again was replaced by the 'dictatorship of the proletariat'. Heaven, gods and other supernatural forces and beliefs had no place in the orthodox materialism. Only recently have the people's traditional beliefs enjoyed a certain amount of freedom and protection from the state authorities. In the cultural sphere, the ideals of a 'new kind of socialist man' replaced the outdated Confucian gentleman. Socialist collectivism replaced the Confucian three yokes and five relationships (tam-cuong, ngu-thuong). A political campaign against individualism dismantled the tradition of strong leadership in the family and society-the Confucian family leader (gia truong) being considered a remnant of the feudalism that socialist society sought to erase.

The socialist conception of social equality destroyed the Confucian views of class. For example, new rich families recruiting household servants now often allege that their servants lack obedience, and when Vietnamese women are sent to work as household servants in Taiwanese families, similar complaints often emerge. This is not surprising given that the 'socialist collective leadership' did not know the terms 'employer and employees'. Instead, people were divided into units (don-vi), where everyone had the right to know, discuss and decide on issues relating to this unit. This characteristic may make the training of the Vietnamese workforce somewhat difficult.

Yet tradition persists. The new ideology has embedded itself in the major aspects of society, from the rules in family matters, to business networks, through to the relationships with public authorities. Indications suggest, however, that the Confucian tradition may have changed in appearance but that the substance is still important in modern Vietnamese life. In the political sphere, the Vietnamese press and political documents sometimes use the term 'Communist' mandarins to refer to this phenomenon. In the economic sphere, the increased autonomy of state-owned enterprises and other institutions, and decreased control of business by bureaucrats and managers, have opened up the possibility of traditional, family-style governance.

From another perspective, Marxism and Confucianism have converged in a number of respects; for example, the primacy of public or common interests over individual interests, the broad and active role of the ruler or state to serve the common interests of the people, and the conception that law is just one of the tools used by the state to maintain social order. This also explains why the Confucian authoritarian style of government may also have contributed its characteristics to Asian Communism (Peerenboom 2002).

Socialist legality, borrowed from the former Soviet Union, broadened its influence and was far more extensive than the French civil law heritage in Vietnam. In essence, the Soviet doctrine saw the law as a tool that the state could use to ensure socialist revolution. More generally, under this doctrine, the legal system existed to serve the interests of the working class. Such a system had to be enforced, even through 
dictatorship of the proletariat if necessary. Under this system, the written legal documents defined the limits of individuals' behaviour, the courts and justice system were reorganised to provide greater justice to the population, and the privileges available to lawyers and judges were curtailed.

In the economic sphere, the socialist production mode was premised on the dominance of state-owned enterprises operating in the framework of a centrally planned economy. Peasants were organised into Soviet-style cooperatives, and private enterprise was extremely limited. In this regard, the Vietnamese state came close to achieving its goal- that people would only be allowed to do what was prescribed by the law. The economic reform occurring today in both agriculture and industry would have been characterised as law-breaking or 'breaking the wall' (vuot-rao) at the time of the centrally planned economy.

During the 1990s, people wishing to open businesses had to apply for numerous licences in order to prove the legality of their actions, and this complex system remained in place until it was simplified in the 1999 Law on Enterprises. This liberalisation, however, was not backed by equivalent changes to contract law and the laws concerning dispute resolution. The power and discretion of the state authorities to intervene in the activities of contracting parties remained unconstrained. Business contracts, for example, may be declared void, often arbitrarily, based on outdated and conflicting regulations.

In the political sphere, the doctrine of 'socialist legality' led to the liquidation of the Ministry of Justice, leaving only one department-'Legality' (Vu Phap Che)within the Office of the Government. Even today, the names of some legal departments in certain ministries (Department of Legality, vu phap che) still refer back to the doctrine of that time. Under 'socialist legality', communal autonomy was extremely limited; traditional village structures were abolished and replaced by the People's Committee and People's Council, similar to the Soviet model. Distribution of funding and other resources was governed by a system of top-down distribution known as 'applications and grants' (xin cho), ${ }^{4}$ in which the resources controlled by the local governments were limited. Only in recent years have local governments enjoyed increased autonomy.

With the new slogan 'socialist state ruled by law', Soviet-style 'socialist legality' disappeared from Vietnamese legal jargon, but its effects on society are far from disappearing. In the justice system, judges still wait for instructions from the Supreme Court and are unable to develop law (make law) in cases where the written legal documents are silent on a particular issue. Likewise, local authorities still wait for circulars and official letters distributed by the ministries to implement a given law, thus making a law merely a set of general principles and leaving the administrative authorities wide discretion in interpreting it. Engaging in business is neither expressly allowed nor prohibited by the law, but may still be interpreted as illegal, as has happened in recent cases where businesspeople were essentially defined as tax frauds or evidencing an intention to break the law. ${ }^{5}$ 


\section{LEARNING FROM ASIAN NEIGHBOURS: WHAT CAN CONFUCIANISM CONTRIBUTE TO CONTEMPORARY LEGAL DEVELOPMENT IN VIETNAM?}

After a century of struggle, the Vietnamese have recognised that learning from their Asian neighbours, Japan, China, Korea and other ASEAN countries, may bring more order and prosperity to their homeland than drawing from the experiences of the former Soviet Union or the Middle East and East Europe. Given their phenomenal growth in the second half of the twentieth century, the East Asian economies' experiences of borrowing Western commercial laws, while also consolidating traditional institutions, appear to carry the most valuable lessons for Vietnam.

The new advances in comparative economics and law show that different circumstances require different institutions to balance the fundamental trade-off between disorder and dictatorship (Djankov et al. 2003). The obstacles that prevent the emergence of rule of law in the former Soviet Union are distinctive from those in China (Stiglitz and Hoff 2002). While the 'big bang policy' may have led to stagnation and disorder in the former Soviet Union, the gradual dual-track economic reform in China has promised to be more successful (Sachs and Woo 1997). By consolidating traditional institutions to promote a market-oriented economy, Confucianism offers a rich source of norms and institutions that could underpin economic and social development in Asia in general, and Vietnam in particular.

Traditional Confucian society is well-known as a 'no law society', where law and legal litigation do not have the same importance as in the West. The ratio of residents to lawyers in the United States is 400:1; 7,000:1 in Japan; and 20,000:1 in Vietnam (Keleman and Sibbitt 2002). Confucian ethics can substitute for some functions of law; hence family capitalism is preponderant in Asia, and Confucianbased government and collectivism substitute and supplement the law to maintain social order and discipline (Kheng-Boon Tan 2000; Branson 2001).

Experiences in other Asian countries where Confucian values have been integrated into legal development may be of interest to Vietnam.

- Confucian heritage. Vietnam shares the common heritage of Confucianism with other East Asian countries. Although Confucianism is based on the received wisdom of generations, it is flexible and can be redefined to meet the modern needs of ensuring harmony and social order. Confucian values and faith can help form new patterns of behaviour and thus contribute informally to achieving the aims of law.

- Confucian state. The process of change from an agricultural nation to an industrialised nation is not possible without strong and careful state intervention. The Confucian state is more responsible than most Western states for serving the interests of the people, and is thus more focused on promoting export-oriented policies and certain other sectoral policies. This intervention encompasses a wide range of activities, from holding 
large shares of public ownership in enterprises to controlling financial resources, facilitating networks and building consensus amongst business and government.

- Confucian view of the primacy of public over individual interests. In times of economic difficulty, collective interests trump individual and civil rights. This approach does not deny outright that stability and economic growth are to some extent concerned with individual liberty, but, when translated into political or economic law, the Confucian views seem to clash with the Western concept of liberal democracy and the rule of law. This trade-off, however, may be of essential importance in Asia's economic growth.

- Culturally specific institutions. Law and social norms need appropriate institutions to transmit behavioural forms to the mass population. The Confucian society reproduced its own institutions to enforce the norms. Despite widespread adaptation of corporate forms, family-based management styles are still prominent, evident in the way that business operators in these countries frequently rely on traditional networks as a way of managing risk. The role of contract, dispute resolution, and bankruptcy laws can only be understood in this context.

- Seeking convergence. The intense integration of Confucian values into the world economy as a result of globalisation emphasises the need to redefine these values to allow them to converge to, and exist alongside, other harmonised legal standards. The economic benefits that would follow lie in the possibilities that Western-based commercial laws offer for more advanced modes of organising and governing business, raising capital, managing risks, and enhancing transactions. The examples of Japan, Korea, Taiwan, Singapore and China show that these capitalist institutions are crucial in facilitating a market-oriented economy. The Japanese and Singaporean governments in particular have taken the initiative in adopting Western commercial law, without being coerced by foreigners. From fine literal translations to borrowing sophisticated theories, the Japanese carefully combined traditional values with Western liberalism, thus promoting the convergence of their cultural roots with foreign ideas. The translation of the Greek word for 'economy' into 'serving the country, helping the world', indicates a mastery in the art of borrowing traditional values for the new needs of modern times. It links the realisation of the Western ego with the Eastern sacrifice for the country, thus making conducting business ethically a highly honoured work. In the same way, Asian business schools, drawing on the long Chinese tradition of the 'art of war', describe business as being similar to military combat. It comes as no surprise then that, in Western eyes, the Japanese and Chinese engage in economic competition as though they are engaged in war. 


\section{CONCLUSION}

After decades of reform, the Vietnamese legal system today resembles a jungle of laws. It is evident that much has to be done if the mess is to be resolved. The scandal of the Nam Cam case and the emergence of criminal networks illustrates not only the weakness of the legal and juridical system, but also the unique response of the market economy to the lack of efficient institutions in this country. Where the long arm of the law cannot reach, traditional norms and structures informed by Confucian values continue to dominate. Confucian values, thus, may positively supplement and strengthen the law but may also challenge and compete with it. In the long run, newly redefined Confucian values may continue to establish social trust, discipline and order in Vietnam.

\section{NOTES}

1 See the Annual Report of the People's Supreme Court, also Duong Dang Hue (2003).

2 For updated economic data of Vietnam, see CIEM (2002).

3 See Tran Van Giau (1998:136), and for a comparative perspective Chongko Choi (1997).

4 'Xin cho' literally means 'ask and give'.

5 See Report of the Working Team of the Government to Implement the Law on Enterprise, available at www.vnexpress.net of May 16, 2003; also the Governmental Decree No 61/1998/ ND-CP dated 15 August 1998 on Inspection of Enterprises.

\section{REFERENCES}

Branson, D.M., 2001. ‘The very uncertain prospect of global convergence in corporate law', Cornell International Law Journal, 34(2):321-61.

Central Institute for Economic Management, 2002. Vietnam's Economy 2001, National Politics Publishing House, Hanoi. Available online at www.ciem.org.vn, www.worldbank.org.vn.

Chongko Choi, 1997. Asian Jurisprudence in the World, Seoul National University Press, Seoul.

Dao Duy Anh, 1930. Vietnam's Culture History, Quan Hai Tung Thu Publishers, Hue.

— 1950. The Origin of the Vietnamese People, The Gioi Publishers, Hanoi.

Dao Tri Uc and Le Minh Thong, 1999. 'Reception of East and West legal values into Vietnam's legal ideology', State and Law, 5: 3-17.

Djankov, S., Glaeser, E.L., La Porta, R., Lopez-de-Silane, F. and Schleifer, A., 2003. The New Comparative Economics, Working Paper 9608, National Bureau of Economic Research, Cambridge, Massachusetts. Available online at www.nber.org/papers/w9068.

Duong Dang Hue, 2003. 'The role of the Bankruptcy Law in present Vietnam', State and Law, 1:30-40.

Dvor, B.A., 1999. 'What is the connection? Vietnam, the rule of law, human rights and antitrust', Houston Journal of International Law, 21:427-49. 
Head, J.W., 2003. 'Codes, cultures, chaos and champions: common features of codification experiences in China, Europe and North America', Duke Journal of Comparative and International Law, 13(1):1-94.

Hizon, E.M., 1999. 'Virtual reality and reality: the East Asian NICs and the global trading system', Annual Survey of International and Comparative Law, 5:81-162.

Keleman, D., and Sibbitt, E., 2002. 'The Americanization of Japanese law', University of Pennsylvania Journal of International Economic Law, 23:269-323.

Kim Dinh, 1969. Differences between East and Western Philosophy, Khai Tri Publishers, Saigon.

—, 1970. Origin of Vietnam's Philosophy, An Tiem Publishers, Hanoi.

Le Van Quan, 1997. Introduction to History of Chinese Ideology, Giao Duc Publishers, Hanoi.

Le Van Sieu, 1968. National Tradition, Hoang Dong Phuong Publishers, Saigon

Ly Te Xuyen, 1961. Viet Dien U Linh Tap, Khai Tri Publishers, Saigon [tr. Le Huu Muc].

Marr, D.G., 2000. 'Concepts of "individual" and "self" in twentieth-century Vietnam', Modern Asian Studies, 34(4):769-96.

Ngo Tat To, 1940. Critic of Confucianism, Mai Linh Publishers, Hanoi.

Nguyen Dang Dung, 2001. Some Issues of Constitution Law and State Apparatus, Giao Thong Van Tai Publishers, Hanoi.

Nguyen Dang Thuc, 1967. History of Vietnam's Ideology, Ministry of Education, Saigon. ,1992. Lich su tu tuong Vietnam [History of Vietnam's Ideology], Volume VI, Ho Chi Minh City Publishers, Ho Chi Minh City.

Nguyen Hien Le, 1958. Confucianism: a political philosophy, Ministry of Education, Saigon.

_- 1992. Iking: the way of gentlemen, Van Nghe Publishers, Westminster

Nguyen Ngoc Huy and Ta Van Tai, 1987. The Le Code: law in traditional Vietnam, Ohio University Press, Athens.

Nguyen Tai Thu, 1993. History of Vietnam's Ideology, Social Sciences Publishers, Hanoi.

_-1997. Influences of Ideologies on Vietnam's Culture, National Politics Publishers, Hanoi

Nguyen The Anh, 1968. Economy and Society under the Nguyen Dynasty, Trinh Bay Publishers, Saigon

Örücü, E., 1999. Critical Comparative Law: considering paradoxes for legal systems in transition, Geschriften van de Nederlandse Vereniging voor Rechtsvergelijking 59, Nederlandse Vereniging voor Rechtsvergelijking, Kluwer International Law, Deventer.

Peerenboom, R., 2001.'Globalization, path dependency and the limits of the law: administrative law reform and the rule of law in the PRC', Berkeley Journal of International Law, 19(2):161-264. 
Peerenboom, R., 2002. 'Let one hundred flowers bloom, one hundred schools contend: Debate rule of law in China', Michigan Journal of International Law, 23(2):471-544.

Phan Dai Doan, 1998. Some Issues of Vietnam's Confucianism, National Politics Publishers, Hanoi.

Phan Dien, 2003. 'Improvement of the ideological work of the Party [Nang cao hon nua cong tac tu tuong, van hoa cua Dang]', Tap chi Cong san, 9 (3/2003).

Phan Ke Binh, 1983. Vietnam's Customs, Song Moi Publishers, Hanoi.

Ruskola T., 2002. 'Legal Orientalism', Michigan Law Review, 101(1):179-235.

Sachs, J.D. and Woo W.T., 1997. Understanding China's Economic Performance, Working Paper 5935, National Bureau of Economic Research, Cambridge, Massachusetts. Available at www.nber.org/papers/w5935/.

Shin Yi Peng, 2000. 'The WTO legalistic approach and East Asia: from the legal culture perspective', Asia-Pacific Law and Policy Journal, 1(2):1-69.

Stiglitz, J., and Hoff, K., 2002. After the Big Bang? Obstacles to the emergence of the rule of law in post communist countries, Working Paper 9282, National Bureau of Economic Research, Cambridge, Massachusetts. Available at www.nber.org/ papers/9282/.

Stoltenberg, C.D., 2000. 'Globalization, Asian values and economic reform: the impact of tradition and change on ethical values in Chinese business', Cornell International Law Journal, 33:711-29.

Tan, E. Kheng-Boon, 2000. 'Law and values in governance: the Singapore way', Hong Kong Law Journal, 30(1):91-119.

Tran Le Sang (ed.), 2002. Five Classical Works, Social Sciences Publishers, Institute of Chinese Studies, Hanoi

Tran The Phap, 1960. Linh Nam Chich Quai, Khai Tri Publishers, Saigon [tr. Le Huu Muc].

Tran Trong Kim, 1971. Confucianism: introduction into Chinese philosophy, Tan Viet Publishers, Saigon (reprinted by Ho Chi Minh City Publishers frequently from 1992-2002).

Tran Van Giau, 1988. Philosophy and Ideology, Ho Chi Minh City Publishers, Ho Chi Minh City.

Truong Ba Can, 1988. Nguyen Truong To: person and literature, Ho Chi Minh City Publishers, Ho Chi Minh City.

Vu Khieu, 1997. Confucianism and Development, Social Sciences Publishers, Hanoi.

Vu Van Khien, 1968. Vietnam's Customs, Duong Sang Publishers, Saigon.

Vu Van Mau, 1958. Introduction into Civil Law, Ministry of Education, Saigon.

—_, 1963. Quelques Aspects Techniques de la Réception des droits Occidienteux, Association Nationale de Droit Compare, Saigon. 